УДК 159:316.61_053.6

DOI:

Зоряна Борисенко, кандидат психологічних наук, доиент кафедри практичної психології Дрогобицького державного педагогічного університету імені Івана Франка

Любов Гаврищак, кандидат психологічних наук, дочент кафедри практичної психологї Дрогобицького державного педагогічного університету імені Івана Франка

Наталія Подоляк, кандидат психологічних наук, доцент кафедри практичної психологї Дрогобицького державного педагогічного університету імені Івана Франка

\title{
ОСОБЛИВОСТІ МІГРАЦЙНИХ УСТАНОВОК СУЧАСНОЇ УКРАЇНСЬКОЇ МОЛОДІ
}

У статті аналізуються дослідження психологів стосовно такого поняття, як міграція у соиіальнопсихологічному аспекті. Зокрема аналізуються психологічні сутність та види міграційних процесів (еміграція, імміграція), причини й особливості міграційних прочесів у сучасній Україні. Авторами проаналізовані особливості міграційних установок сучасної украӥнської молоді та вплив на їх формування таких чинників, як вік, стать, місие проживання та дотичність до процесу міграиії.

Ключові слова: міграчія; імміграџія; еміграџія; трудова міграџія; адаптивна здатність; міграційна установка.

Jim. 10.

Zoryana Borysenko, Ph.D.(Psychology), Associate Professor of the Practical Psychology Department, Drohobych Ivan Franko State Pedagogical University

Lyubov Havryshchak, Ph.D.(Psychology), Associate Professor of the Practical Psychology Department, Drohobych Ivan Franko State Pedagogical University

Nataliya Podolyak, Ph.D.(Psychology), Associate Professor of the Practical Psychology Department, Drohobych Ivan Franko State Pedagogical University

\section{THE FEATURES OF MIGRATION INSTALLATIONS OF MODERN UKRAINIAN YOUTH}

The article is devoted to the question of psychological researches into such notion as migration in the socialpsychology aspect. In particular psychological essence and types of migration processes (emigration, immigration), reasons and features of migration processes in modern Ukraine are analyzed. The authors analyzed particularities of migration installations of modern Ukrainian youth and impact on its formation such factors, as age, sex, place of residence and relevance to the migration process.

Now we often have to hear that living abroad is better and happier than living at home. We hear it everywhere: among publications in the periodical press, among the many comments in the media, on the radio and on TV. Acting in this case there is a psychological mechanism of infection, when euphoric, often consciously exaggerated impressions of life in other countries of people who were already there and arrived at home, increases the number of people willing to leave. This affects the decision to migrate. Many people have a desire to leave their homes and seek happiness in other countries. Some people want to go to well-developed foreign countries to live more comfortably and earn more money. When person is abroad, he has more chance to find well-paid job, that people can enjoy better financial opportunities. For example, they may get a good job and a high salary so they can buy what they want and have a better lifestyle. Also, living abroad is a good reason to learn a new language. We consider the migration problem to be relevant today due to the fact that young people migrate massively; 5 to 7 million people were departed from Ukraine (according to unofficial statistics, they are much more). The systemic crisis of Ukrainian society, which has been going on for more than a decade and seems to be not resolved, soon, creates an atmosphere in the sphere of public consciousness. Under these conditions, emigration has become widespread among Ukrainian citizens.

Keywords: migration; immigration; emigration; labor migration; adaptability; migration attitude.

П остановка проблеми. У сучасних 3МІ нерідко доводиться чути думки про те, що за кордоном життя краще, щасливіше, стабільне і багате. Відповідно, ідея “далекого раю” викликає бажання у багатьох українців, особливо серед молоді, залишати рідні домівки і шукати щастя у чужих краях. Дієвим при цьому є механізм зараження, коли ейфорійні, часто свідомо перебільшені враження про життя

3. Борисенко, Л. Гаврищак, Н. Подоляк, 2020 в інших країнах людей, які там вже були і приїхали у відпустку додому, збільшує кількість охочих виїхати. Попри це, часто люди не усвідомлюють і не враховують ті негативні наслідки, які обов'язково будуть в їх родинах, зокрема, і в державі загалом, оскільки в житті нічого не минає безслідно. Та й не хочеться, щоб Україна перетворилася на країну пенсіонерів.

Аналіз останніх публікацій. Найбільше

Молодь і ринок №3-4 (182-183), 2020 


\section{ОСОБЛИВОСТІ МІГРАЦЙНИХ УСТАНОВОК СУЧАСНОЇ УКРАЇНСЬКОЇ МОЛОДІ}

досліджень стосовно питання міграції стосуються ії видів. Наприклад, А. Адеподжу виокремлював види міграцій на основі їх тривалості. А. Ічдуйгу за основу класифікації взяв офіційність перебування за кордоном. Зі свого боку С. Каслз вивчав види міжнародних міграцій на основі волі самих мігрантів. Е. Мокозник визначає п’ять основних різновидів міграції через призму мети приїзду. М. Тоба виокремлює всього три категорії емігрантів (переселенці - назавжди залишають батьківщину; візитери - довший час проживають в чужій країні (студенти, дипломати, бізнесмени) та туристи [2].

Мета статті полягає у теоретичному вивченні психологічної сутності міграційних процесів, а також особливостей, причин, видів, мотивів та установок стосовно міграції серед української молоді.

Виклад основного матеріалу дослідження. Загалом таке соціальне явище, як міграція, відбувається упродовж всієї історії людства. Існує багато визначень поняття та сутності міграції. Соціологічний словник трактує міграцію як “географічний рух індивідів або певних груп індивідів, тобто мобільність людей у вужчому або ширшомугеографічномупросторі” [11,224]. А. Хомра під терміном міграція розуміє “територіальні переміщення людей, пов'язані зі зміною місця проживання" [6, 148].

Дещо ширше визначення міграції запропонував В. Шелюк: "Міграція - це поняття, яке відображає демографічні і соціально-економічні процеси, сукупність переміщень, які здійснюються людьми між регіонами однієї країни, країнами, різного виду поселеннями та інші види переміщень" [7, 46-47].

Поняття міграції включає у себе такі два явища, як еміграція та імміграція. Загалом еміграцію трактують як вимушену чи добровільну зміну місця проживання людей (емігрантів, переселенців), переселення зі своєї батьківщини в інші країни глобального суспільства з економічних, політичних або релігійних причин. Натомість імміграція - це в’їзд (вселення) громадян однієї держави в іншу на постійне чи тимчасове (як правило, тривале) проживання [1].

Існує багато класифікацій видів міграції залежно від критеріїв. Саме цим питанням займалися такі вчені, як А. Адеподжу, А. Ічдуйгу, С. Каслз, Е. Мокозник, С. Трубич та інші.

В Україні на сьогоднішній день актуальною $€$ трудова міграція. Це міграція людей, які в результаті погіршення економічної ситуації виїжджають на певний час на роботу до іншої країни. С. Трубич виокремлює три види міграції 3 метою працевлаштування. Перший - це робота за спеціальністю, одержаною раніше, та за спеціальністю, яка їй не відповідає. Наступним видом $є$ міграція висококваліфікованих кадрів (“інтелектуальна міграція" або “відплив мізків”). Третій вид трудової міграції - інтелектуальна (робота вчених, що працюють за спеціальністю на основі короткотермінових чи довготермінових контрактів) $[5,29]$.

3 отриманням Україною незалежності міграція стала доступною кожному. Наразі ситуація в державі є дуже проблемною і важкою: воєнні дії на Сході, анексія Криму, падіння рівня і якості життя, нестача робочих місць, низька заробітна платня, інфляція, що веде до росту цін на продукти харчування, медичне обслуговування, навчання. Варто зазначити, що спрощення умов перетину кордону до країн СС також сприяє міграції. Можливо тому Україна відіграє одну з основних ролей у загальносвітовій тенденції масової міграції. Вона входить до першої десятки країндонорів міжнародних мігрантів. Українці становлять понад 10 \% від загальної кількості мігрантів, яких станом на 2018 рік є від 150 до 175 млн осіб (тобто понад 3 \% населення планети Земля), що живуть за межами рідної країни, а понад 20 млн українців постійно проживають за межами країни свого походження і $є$ вже громадянами інших держав [8]. Як результат, на сьогодні в Україні існують глобальні проблеми 3 демографічною ситуацією. Вона характеризується від’ємним сальдо міграції, негативною динамікою смертності та народжуваності.

Загалом в Україні сформувалися два основні вектори трудової міграції - східний та західний. Більш популярним серед молоді й найбільш оптимальним для висококваліфікованих працівників є саме західний. Ним можна вважати рух до: Західної Європи, США, Канади та інших розвинутих країн заходу. Метою вказаної міграції може бути не тільки поліпшення власного матеріального стану, але й більшою мірою натуралізація (набуття громадянства). Міграція висококваліфікованих працівників може бути незворотною втратою людського та трудового капіталу України. Міграції до країн СНД-східний вектор. Він $\epsilon$ популярним серед мігрантів 3 незнанням іноземної мови, недостатньою кваліфікацію чи низькою адаптивною здатністю [3].

Особливого значення набуває проблема міграції серед молоді. Молодь найбільше хоче мігрувати та працевлаштуватися за кордоном через бажання реалізуватися як спеціаліст чи отримати досвід роботи у міжнародних компаніях та організаціях. Майже половини трудових 
мігрантів - від 18 до 25 років, відповідно кількість довгострокових трудових мігрантів, які не повертаються до України, зростає. Крім того, кількість українських студентів, що навчаються за кордоном, з кожним роком збільшується. Це додатковий ризик для українського ринку праці [9].

Студентська молодь $є$ представником основних провідників цінностей у майбутнє. Також у багатьох соціологічних наукових роботах студентів відносять до соціальної групи, яка за своїм суспільним становищем належить до інтелігенції і призначена для занять висококваліфікованою працею у різних галузях науки, техніки, культури, $\epsilon$ державним резервом.

Наше дослідження стосувалося

міграційних установок і настроїв сучасної української молоді. У дослідженні були використані анкети Міжнародного інституту освіти, культури та зв'язків 3 діаспорою НУ “Львівська політехніка", що були адаптовані згідно з метою і завданнями нашого дослідження [4]. Питання анкети розкривали міграційні настрої та установки молоді, а саме: мету, бажання, причини та бачення свого майбутнього. До анкетування були залучені випускники шкіл та студенти-випускники.

Вибірку нашого дослідження склали студенти випускних курсів ДДПУ імені Івана Франка різних факультетів та учні-випускники ЗОШ № 1 м. Дрогобич, Боринського НВК Турківського рну Львівської обл. та Турківської ЗОШ № 1. Загалом вибірка становила 107 досліджуваних, 3 них 42 студенти етвертих курсів та 65 учнів 11 класів.

Вік студентів коливається у межах від 20 до 21 років. Серед опитаних респондентів $24(57,1 \%)$ жіночої статі та 18 (42,9\%) чоловічої. Більшість студентів на час опитування були неодруженими - 39 (у відсотках - це 92,85). Вік учнів коливається у межах від 16 до 17 років. Серед опитаних респондентів 29 (44,6 \%) жіночої статі та $36(55,4 \%)$ чоловічої.

Зі всієї кількості опитаних учнів і студентів було виявлено групу випускників, які були категоричні у небажанні покидати Україну. Це 12,3 \% учнів та $11,9 \%$ студентів. Учнів, що вже встигли побувати за кордоном, $-36,9 \%$, а студентів 57,1\%.

Аналізуючи отримані результати, можна констатувати різні рейтинги одних і тих самих мотивів залежно від віку опитаних. Серед учнів першими у рейтингу мотивів є цікаве і приємне проведення часу: туризм - 92,3 \% та відвідини родичів $-67,7 \%$. Наступні мотиви за значимістю - робота та навчання за кордоном (53,8 \% і 35,4\%). Найменш значимими для учнів є змагання, конференції та олімпіади (12,3% і 2 \%).
Для студентів-випускників на першому місці стоїть робота - 57, \%. Значущим мотивом залишається туризм і для студентів - 40,5\%. Подальше навчання за кордоном займає третю позицію у рейтингу. Таку різницю ми пояснюємо віковими особливостями психічного розвитку та соціальною ситуацією учнів і студентів. Серед учнів найбільш вагомими причинами можливого виїзду закордон $є$ : можливість збільшення матеріального статку (73,8 \%), бажання оволодіти знаннями і навичками, що не доступні на батьківщині (69,2 \%), відсутність роботи в Україні $(47,7 \%)$ та наявність батьків чи близьких родичів, що проживають та працюють за кордоном $(32,3 \%)$.

Менш значущими причинами виїзду для учнів є: рівень корупції в Україні (29,2 \%), бажання фахової самореалізації, надія на кращі умови роботи за межами України (23\%), якість медичного обслуговування (16,9\%), професійна нереалізованість в Україні (13,8 \%) та небажання залишатися в Україні (3,1 \%).

Натомість серед студентів, які бажають виїхати закордон, про безробіття в Україні як чинник міграції зазначають 95,4 \%, а серед усіх респондентів - 92,9 \%. Вагомим чинником, що спонукає студентську молодь виїжджати закордон, є можливість збільшення матеріального статку - 78,6 \%, а також бажання фахової самореалізації - 54,8 \% та наявність батьків чи близьких родичів, що проживають та працюють за кордоном. Варто зазначити, що рівень корупції в Україні не виявився достатньо вагомим чинником міграції.

Ми вважаємо, що саме життєві задачі та перспективи, які стоять перед випускниками школи та 3ВО, визначають зміну рейтингу міграційних мотивів.

Нагадаємо, що більше половини усіх опитаних студентів (57,7 \%) мають бажання виїхати за кордон. При цьому найбільша кількість охочих мігрувати - студенти IФМЕІТ, інституту іноземних мов та майбутні психологи. На нашу думку, це пояснюється актуальністю цих професій в інших країнах та знанням мови. Найменший відсоток охочих виїхати 3 країни припадає на студентів філологічного факультету.

У ході здійсненого дослідження було також виявлено, що бажання мігрувати найбільшою мірою проявляють фінансово залежні студенти Так, найменше бажання поїхати закордон задекларували респонденти, які є фінансово незалежними та забезпечують себе достатньою мірою. Студенти, які навчаються на комерційній основі, більш схильні до виїзду закордон, ніж ті, 
хто навчаються на бюджетній основі: 11,8 2\% проти $5,63 \%$.

Стосовно учнів прослідковується така тенденція. Загалом 35,4 \% учнів вказали, що мають бажання мігрувати. Найменший відсоток таких припадає на школярів сільської місцевості. Більше охочих проживають у містах. Ці факти наводять на думку, що в молоді наявна потреба в змінах: $з$ менших міст хочуть переїхати в більші або частіше мігрують, а жителі сіл надають перевагу переїзду в місто та в рідших випадках мігрують.

Нас також цікавило питання бачення молоді свого майбутнього за межами своєї країни. Нагадаємо, що серед них $є$ й ті, хто бачить своє майбутнє лише в Україні. Таких респондентів виявилося серед учнів - 12,3 \% та серед студентів $-11,9 \%$.

Ми виявили, що бачення власного майбутнього учнями та студентами істотно відрізняються. На роботу планують поїхати $80,3 \%$ студентів, а учнів - 20,4 \%. Натомість в учнів високий показник бажання навчатися закордоном - 61,9 \%, тоді як у студентів - 24,6 \%. 3 кожним роком молодь все частіше обирає навчання в Європі, Канаді та США. Ця тенденція пояснюється престижністю навчання та високою перспективою працевлаштування як за кордоном, так і в Україні. Стосовно бажаних країн для молоді можемо констатувати, що як для учнів, так і для студентів країнами-фаворитами є: Англія, США, Канада, Польща, Чехія, Італія, Об'єднані Арабські Емірати та Франція.

Бачення майбутнього серед учнів і студентів різниться також і в часовому плані (зручний термін перебування за кордоном). Частка студентів, які виявляють бажання мігрувати на термін не більше одного року, становить 53,4 \%, а учнів $61,4 \%$.

Дотичність до міграції також є вагомим чинником вибору свого майбутнього. 36,9 \% учнів були за кордоном (тут варто звернути увагу на молодий вік респондентів) та $67 \%$ мають родичів 3 трудовим міграційним досвідом. Студентів побувало закордоном 57,1 \% (більше половини) та $71,3 \%$ мають родичів 3 трудовим міграційним досвідом.

Проведене опитування засвідчило, що більшість учнів вважають наслідки міграції негативними, оскільки трудова міграція руйнує шлюби, сім'ї, позбавляє дітей батьків. 13,8 \% не змогли однозначно відповісти на запитання, адже не мають такого досвіду і лише 4,7 \% вважають, що трудова міграція має позитивні наслідки для сім'ї в аспекті поліпшення матеріального становища.
У студентів дещо інакше бачення наслідків міграції. Так 39,1 \% вважають, що міграція має позитивні наслідки для сім’ї, адже поліпшується матеріальне становище, негативними наслідки бачать - 51,3 \% студентів та не можуть відповісти $9,6 \%$.

Отже, як засвідчило наше емпіричне дослідження, існують відмінності в мотивах та причинах бажання залишити свою країну та баченні власного майбутнього серед учнів та студентів, які необхідно знати і враховувати при розв'язанні проблеми трудової міграції молоді.

\section{ЛІТЕРАТУРА}

1. Демографический энциклопедический словарь / Под ред. Д.И. Валентей. Москва: Советская энциклопедия, 1985. С. 251.

2. Міграційні процеси в сучасному світі: світовий, регіональний та національний виміри: (Понятійний апарат, концептуальні підходи, теорія та практика). Енциклопедія/Упоряд. Ю.І.Римаренко;Заред.Ю.Римаренка. Київ: Довіра, 2004. С. $912-914$.

3. Піскун О., Прибиткова І., Волович В. Міграційна ситуація в Україні. Політична думка. 2016. № 8. С. 45 -72 .

4. Прибиткова I. Сучасні міграційні процеси: теоретико-методологічні аспекти досліджень. Соиіологія: теорія, методи, маркетинг. Київ, 2018. № 1. С. $161-172$.

5. Трубич С. Міграційні процеси і зайнятість населення. Вісник Львівського університету (Серія міжнародні відносини). 2009. Вип. 1. С. $398-403$.

6. Хомра А.У. Миграция населения: вопросы теории, методики исследования. Київ: Наукова думка, 1999. C. 148.

7. Шелюк В. Соціальна міграція: Етапи, функції, типи. Перспективи. 2001. № 3 (15). С. 46 - 47.

8. URL:https://www.google.com/url?sa $=t \&$ source=web\&rct=j\&url=https://www.oecd.org/els/mig/ RUSSIAN.pdf\&ved=2ahUKEw iCvKi X1YHiAhVwp YsKHepZCigQFjAAegQIBRAC\&usg=AOvVaw26UTOeAt1ndqdcVLNFfs7

9. URL:http://miok.lviv.ua/wp-content/uploads/2015/ 03/zvitpj.pdf(38)

10. Geist B. Sociologicky slovnik. 2002. 580 c.

\section{REFERENCES}

1. Demograficheskij jenciklopedicheskij slovar (Ed.). Valentej D.I. (1985). [Demographic encyclopedic dictionary]. Moscow, 251 p. [in Russian].

2. Mihratsiini protsesy v suchasnomu sviti: svitovyi, rehionalnyi ta natsionalnyi vymiry: (Poniatiinyi aparat, kontseptualni pidkhody, teoriia ta praktyka) (2004). [Migration processes in the modern world: global, regional and national dimensions: (Conceptual apparatus, conceptual approaches, theory and practice)]. Encyclopedia. (Ed.). Rimarenko Yu. Kyiv. pp. 912-914. [in Ukrainian].

3. Piskun, O., Prybytkova, I. \& Volovych, V. (2006). 
Mihratsiina sytuatsiia v Ukraini [The migrational situation in Ukraine]. Political thought. No.8. pp. $45-72$. [in Ukrainian].

4. Prybytkova, I. (2011). Suchasni mihratsiini protsesy: teoretyko-metodolohichni aspekty doslidzhen [Modern migration processes: theoretical and methodological aspects of research. Sociology: theory, methods, marketing]. Sociology: theory, methods, marketing. Kyiv, No.1, pp. 161 - 172. [in Ukrainian].

5. Trubych, S. (2009). Mihratsiini protsesy i zainiatist naselennia [Migration processes and employment]. Journal of Lviv National University. Series: International relations. Lviv, vol.1, pp. 398 - 403. [in Ukrainian].

6. Homra, A.U. (1999). Migracija naselenija: voprosy teorii, metodiki issledovanija [Population migration: questions of theory, research methods]. Kyiv, 148 p. [in Russian].

7. Sheliuk, V. (2001). Sotsialna mihratsiia: Etapy, funktsii, typy [Social migration: Stages, functions, types]. Perspectives, No. 3 (15), pp. 46-47. [in Ukrainian].

8. Availableat:https://www.google.com/url?sa $=t \&$ source=web\&rct=j\&url=https://www.oecd.org/els/mig/ RUSSIAN.pdf\&ved=2ah UKEwiCvKiX1 YHiAh VwpYsK HepZCi gQFjAAeg QIBRAC \&usg= AOvVaw26UTOeAt1ndqdcVLNFfs7

9. Available at: http://miok.lviv.ua/wp-content/ uploads/2015/03/zvitpj.pdf(38)

10. Geist, B. (2002). Sociologicky slovnik [Sociological dictionary]. 580 p. [in Polish].

Стаття надійшла до редакції 04.06.2020

УДК 373.3.016:004

DOI:

Іван Василиків, кандидат педагогічних наук, старший викладач кафедри математики, інформатики та методики їх викладання у початковій школі Дрогобицького державного педагогічного університету імені Івана Франка

\section{ПРОПЕДЕВТИКА КУРСУ “ІНФОРМАТИКА” В ПОЧАТКОВІЙ ШКОЛІ}

У статті проаналізовано необхідність вивчення інформатики, починаючи з молодчого шкільного віку; розглядаються цілі, які поставлені перед учителем та учнями при вивченні інформатики в початковій цколі. Проведення уроку із застосуванням IT вимагає від вчителя як власних навичок ефективного використання IT, так і знань методів застосування циих технологій у початковій школі, а також санітарно-гігієнічних вимог і вікових особливостей учнів. Комп 'ютерна підтримка вивчення базових предметів вимагає для практичної реалізації изього процесу відповідної підготовки вчителів початкових класів засобами IT.

Ключові слова: інформатика; початкова школа; наступність навчання; IT; інформачійна культура.

Jim. 10.

Ivan Vasylykiv, Ph.D.(Pedagogy), Senior Lecturer of the Mathematics, Informatics and Methods of Teaching in Primary School Department Drohobych Ivan Franko State Pedagogical University

\section{PROPEDEUTICS OF THE COURSE "INFORMATICS" IN PRIMARY SCHOOL}

The article deals with the necessity of studying of computer science, starting from primary school age; the goals set for the teacher and students in the study of computer science in primary school are considered. Conducting a lesson with the use of IT requires from the teachers both their own skills of effective use of IT, and knowledge of methods of application of these technologies in primary school, as well as sanitary and hygienic requirements and age characteristics of students. Computer support for the study of basic subjects requires for the practical implementation of this process the appropriate training of primary school teachers.

In modern conditions, the following tendencies can be distinguished: the teacher is increasingly free from some didactic functions, in particular control, leaving behind creativity; his/her role changes significantly, and the possibilities of managing the cognitive activity of students expand; qualitative characteristics of educational activity change, new didactic functions are transferred to information technologies (presentation of educational information, demonstration of processes and phenomena); the requirements for computer training of teachers are growing.

The information and communication support of the educational process develops the visual, effective, intuitive, creative types of student thinking; communication skills; forms the ability to make optimal decisions or propose the solutions in difficult situations; develops skills of self-education and self-control; lays the foundations of information culture and the beginnings of information processing skills.

Keywords: Computer Science; Elementary School; continuity of training; IT; information culture.

П

остановка проблеми. Наша дійсність диктує свої умови для комфортного і успішного “вливання" дітей у доросле життя. У постіндустріальному світі, в якому ми 3 вами живемо, існує чітка необхідність у тому, що люди могли $з$ легкістю здійснювати всі необхідні 